НОЧВИНА Белла Анатольевна - кандидат исторических наук, доцент кафедры истории, регионоведения и журналистики Нижегородского государственного лингвистического университета им. Н.А. Добролюбова (603155, Россия, г. Нижний Новгород, ул. Минина, 31a; bella.nochtvina@ mail.ru)

\title{
ВЛИЯНИЕ ГРАЖДАНСКИХ ИНИЦИАТИВ НА ТРАНСФОРМАЦИЮ ПАРТИЙНОЙ СТРУКТУРЫ ФРГ
}

Аннотация. Данная статья посвящена кризису репрезентативности партийной системы ФРГ. Главное внимание уделено эволюции основных политических партий Германии в период после объединения. $B$ статье предпринята попытка оценить перспективы изменения политической структуры ФРГ, отношений между политическими партиями и избирателями. Автор дает анализ феномена партийного государства Германии в условиях повышения электоральной неустойчивости. В этой связи гражданская инициатива является методом расширения горизонтали представительной демократии. В статье рассматривается способность гражданских инициатив как формы политической борьбы создавать устойчивые альтернативные политико-партийные объединения.

Ключевые слова: партийное государство, гражданская инициатива, избирательная система, репрезентативность, народные партии

Характерной особенностью современной германской демократии является феномен партийного государства. На сегодняшний момент уже продолжительное время у власти в ФРГ находится так называемая большая коалиция, сформированная из блока ХДС/ХСС и партии СДПГ. Образование такого вида коалиции ряд политологов рассматривают как кризис партийной системы страны. Проявлением кризиса становится и снижение уровня доверия граждан к традиционным «народным» партиям, сокращение численного состава партий, уменьшение явки избирателей на выборы как федерального, так и земельного уровней. Данный процесс трансформации системы народных партий наблюдается во многих европейских государствах. Причины этого следует искать в социокультурных изменениях постиндустриального западного общества, которые привели к появлению нового типа политических партий, для которых характерны прагматизм, использование иной электоральной стратегии и новой модели коалиционных отношений. Репрезентативный кризис народных партий усиливает дальнейшую трансформацию партийной системы ФРГ, определяющим вектором которой становится усиление влияния гражданских инициатив.

Правовой статус партий в ФРГ регламентируется Основным законом (ст. 9; 21) [Deutsche Verfassungsgeschichte... 1994: 97] и федеральным законодательством, в т.ч. законом о политических партиях 1967 г. (с последующими изменениями и дополнениями) ${ }^{1}$.

В конце 1960-х гг. получила развитие новая форма базисно-демократического политического участия - гражданская инициатива. В последующем данная форма не только станет полноправной составляющей «партийного государства» ФРГ, но и новым методом рекрутирования политических элит страны. В качестве гражданских инициатив выступает спонтанное объединение людей, которые в большинстве случаев действуют на локальном уровне для устранения

1 Parteiengesetz. Доступ: https://www.bundestag.de/blob/189336/2d8fc37801c04ccfe153686a39e477e3/ pg_pdf-data.pdf (проверено 01.10.2018). 
просчетов политики земельного или федерального правительства. Так, например, в 1970-х гг. ухудшение экологической обстановки способствовало появлению «зеленого» движения, а миграционный кризис в Европе начала XXI в. привел к формированию в Германии неоконсервативного движения - партии «Альтернативный выбор».

Особенностью гражданских инициатив как метода политического действия является концентрация на конкретных целях, способность мобилизовать за короткое время большое число сторонников, рекрутирование приверженцев своих взглядов и действий из средних слоев населения с высоким уровнем дохода и образования.

Это позволяет им усиливать свою активность на межрегиональном уровне и в будущем формировать устойчивые партийные объединения, например такие, как Партия демократического социализма, которая образовалась из гражданских инициатив бывшей ГДР.

Заслугой гражданских инициатив служит то, что они внесли в общественное сознание такие политико-социальные проблемы, которые недооценивались и народными партиями, и многочисленными союзами по интересам. Однако акции гражданских инициатив не всегда положительно влияют на эффективность германской демократии. Достаточно часто гражданские инициативы претендуют на компетентность в принятии решений, которые являются прерогативами демократически избранных органов власти, пытаются проводить интересы меньшинства общества в противовес интересам большинства, а также используют в качестве тактики политической борьбы насилие. Критикуя традиционные партии за разрыв с интересами избирателей и коррумпированность, сами гражданские инициативы активно используют популизм и ангажированность средств массовой информации в своих эгоистических интересах для получения доступа к федеральному уровню власти.

Появлению новых социальных движений, как обозначают гражданские инициативы в западной политологии, способствовал общий кризис доверия немецких избирателей к традиционным методам электоральной политики со стороны крупнейших политических партий страны. В конце 1960-х гг. актуальной внутриполитической проблемой становится расширение компетенций модели социального государства, что выражалось в требовании профсоюзов ввести практику «соучастия в управлении производством». Введение ответных чрезвычайных законов в 1968 г. со стороны правительства не только наглядно показало кризис христианско-демократической концепции «социального государства», но и стало началом массовым протестных выступлений. Образование первого правительства «большой коалиции», основанного на принципах континуитета программных установок СДПГ и ХДС/ХСС, новый взлет популярности идей левого радикализма в Европе, общий экологический кризис в развитых индустриальных странах ЕС - все это сделало гражданские инициативы (Bürgerinitiativen) эффективным методом политического действия в глазах избирателей. Гражданские инициативы предлагали прямую форму демократии, основанную на общности собраний и интересов всех участников движения, праве свободного членства и активных действий в решении конкретных проблем.

Формирование вначале 1970-х гг. леволиберального правительства не смогло остановить рост политического влияния гражданских инициатив. Катализатором стало принятие правительством СДПГ/СвДП программы строительства новых АЭС в ФРГ.

Экологическое движение, стоящее у истоков образования партии «Зеленые», было определяющим среди протестных движений 1970-1980-х гг., но граж- 
данские инициативы также стимулировали активизацию таких традиционных социальных движений, как пацифистское, женское, рабочее.

Интересно, что основателем «зеленого» Движения в ФРГ считается лидер студенческих организаций Р. Дучке, который также был идеологом $R A F$.

Среди многочисленных и зачастую разрозненных гражданских инициатив наибольшей консолидации достигли экологисты. В 1972 г. они создают Федеральное объединение гражданских инициатив защиты окружающей среды, а 1980 г. в Карлсруэ завершилось программное образование новой общенациональной партии «Зеленые».

Главным участником новых социальных движений стала немецкая молодежь, т.к. проведенная правительством СДПГ/СвДП реформа снижения возрастного ценза для избирателей способствовала активизации политической ангажированности молодых избирателей. В связи с этим гражданские инициативы часто позиционировали себя как альтернативу традиционной представительной демократии, требовали расширения принципов прямого демократического выбора в принятии решений по социально-политическим проблемам.

Поражение радикальных протестов, спад влияния идей левого радикализма привели к преобладанию в гражданских инициативах концепции синтеза элементов прямой и представительной демократии.

Будущая партия «Зеленые», используя в пропагандистских целях экологический алармизм, одновременно выдвигала программные требования новых реформ и позиционировала себя как новую антипартию. Экологисты умело маневрировали на политической арене ФРГ, закрепив за собой определенный процент электората и создавая площадку для дальнейшей эволюции модели гражданской инициативы в процессе включения в общую партийную систему страны. В последующем политический опыт экологического движения будет использоваться другими гражданскими инициативами как инструмент партийной институционализации.

В современной западной политологии изучению феномена гражданских инициатив посвящено целое направление - NSB-Forschung. Теория социальных движений в большей степени рассматривает гражданские инициативы через призму коллективного поведения, действия, отмечая его социокультурные причины и предпосылки, постмодернистскую мотивацию [Хабермас 2003: 112].

Так, известный немецкий философ и социолог Ю. Хабермас в своих работах отмечает иную социокультурную мотивацию новых моделей гражданского участия, их ориентацию на постматериалистические ценности в условиях информационного техногенного общества [Хабермас 2000: 152]. Фрагментация, отсутствие четкой коллективной идентичности, незащищенность интересов слабо организованных групп заставляет гражданские инициативы искать прямой путь к публичной политике. Хабермас исследует гражданские инициативы как новый вариант социального конфликта, как стремление общества расширить социальные лифты власти, обеспечить действенную демократию в новых исторических реалиях. Гражданские инициативы сочетают, по его мнению, прямое действие со стихийной формой участия, расширяя политическую ангажированность электората и заражая своим примером традиционные социальные движения представительной демократии, например профсоюзы.

Э. Гидденс определяет гражданские инициативы как «коллективную попытку осуществить общие интересы или добиться общей цели посредством коллективного действия вне рамок установленных институтов» [Гидденс 2005: 580]. По его мнению, гражданские инициативы как неинституциональные формы представительства интересов различных социальных групп берут на себя роль 
посредника между обществом и государством, т.е. ту роль, которую не могут уже в полной мере осуществлять традиционные народные партии.

Однако возникает вопрос: насколько данные новые альтернативные формы политического действия являются действенной оппозицией народным партиям?

Рассмотрим данный вопрос на примере институционализации партии «Зеленые». Основополагающая партийная программа «зеленых» была принята в 1980 г. в Саарбрюккене. Состав партии был весьма разнообразным - от правых либералов до радикалов левого толка, руководящие позиции занимали левоцентристы. Характеризуя тенденцию развития электоральной политики партии «Зеленые», отметим, что расширение поддержки избирателей происходило путем эволюционной трансформации идеологической концепции партии. Отход от своих первоначальных позиций и определенная деидеологизация предоставили «Зеленым» возможность привлечения новых избирателей и создания новых коалиций. Гарантии прав меньшинства, учет всех внутрипартийных мнений стали для партии экологистов залогом будущих правительственных коалиционных компромиссных решений.

Первичные предвыборные лозунги экологизма, пацифизма, расширенной социальности, децентрализованной прямой демократии, а также внутрипартийный организационный принцип, предоставлявший широкую автономию и самостоятельность земельным партийным объединениям, способствовали включению в ряды «Зеленых» разрозненных остатков левых социальных движений. Уже в начале 1980-х из партии уходят консервативные экологисты, создав впоследствии собственную партию, а также в 1983 г. «зеленые» впервые получают места в бундестаге. Объединение партии в 1993 г. с восточногерманским «Союзом 90-х» показало дальнейшую идеологическую направленность партии, сделав возможным создание прочной правительственной коалиции между партией «Зеленые/Союз 90» с СДПГ с 1998-2005 гг.

Эволюции партии «Зеленые» способствовали не только внутренний раскол и неудача экологического движения (проблема создания новых АЭС до сих пор остается актуальной для ФРГ), но и сближение политического курса Й. Фишера с программой СДПГ «Новый либеральный центр» Г. Шредера. Оценивая современные идеологические позиции «Зеленых», отметим снижение популярности партии с 10,7\% (выборы 2005 г.) до 8,7\% (выборы 2017 г.) ${ }^{1}$ и обсуждение лидерами блока ХДС/ХСС создания варианта правительственной коалиции с партией СвДП и партией «Зеленые», т.е. так называемой ямайской коалиции. Внутриполитические причины и объективные обстоятельства в настоящее время не позволили сложиться подобной коалиции, но это не отрицает возможность создания данной правительственной коалиции в будущем.

В целом, оценивая итоги влияния гражданских инициатив на трансформацию партийной системы ФРГ, следует отметить, что новые социальные движения, возникающие как альтернатива народным партиям, впоследствии принимают форму и парадигму традиционных партий. Это характеризует устойчивость немецкого «партийного государства» как модели внутрипартийной интеграции и политического идентичности.

\section{Список литературы}

Гидденс Э. 2005. Социология (при уч. К. Бердсолл, пер. с англ.). 2-е изд., полн. перераб. и доп. М.: Эдиториал УРСС. 632 с.

1 ЦИК Германии огласил результаты выборов в бундестаг. Доступ: https://vz.ru/news/2017/9/25/ 888371.html (проверено 06.10.2018). 
Хабермас Ю. 2000. Моральное сознание и коммуникативное действие (пер. с нем., под ред. Д.В. Скляднева). СПб: Наука. 380 с.

Хабермас Ю. 2003. Философский дискурс о модерне (пер. с нем.). М.: Весь Мир. $416 \mathrm{c}$.

Deutsche Verfassungsgeschichte 1848-1919-1949 (hrsg. H. Schulze). 1994. F.a.M: Lang. $489 \mathrm{p}$.

NOCHVINA Bella Anatol'evna, Cand.Sci. (Hist.), Associate Professor of the Chair of History, Regional Studies and Journalism, Linguistic University of Nizhny Novgorod (31a Minina St, Nizhny Novgorod, Russia, 603155; bella. nochtvina@mail.ru)

\title{
INFLUENCE OF CIVIL INITIATIVES ON THE TRANSFORMATION OF GERMANY PARTY STRUCTURE
}

\begin{abstract}
The article is devoted to the crisis of representativeness of the party system in Germany. The author pays the main attention to the evolution of the main political parties in Germany in the period after reunion. The article considers the evolutionary transformation of people's parties, their role in the political system of representative democracy. The author analyzes the phenomenon of the party state of Germany in conditions of increasing electoral instability. In this regard, civic initiative is a method of broadening the horizon of representative democracy. The article considers the ability of civil initiatives as a form of political struggle to compose sustainable alternative political party associations. Assessing the results of the influence of the civil initiatives on the transformation of the party system in the Federal Republic of Germany, the author notes that the new social movements that emerge as an alternative to the people's parties subsequently take the form and paradigm of traditional parties.
\end{abstract}

Keywords: party state, civil initiative, electoral system, representativeness, people's parties 